\title{
Detection of microplastics in Litopenaeus vannamei (Penaeidae) and Macrobrachium rosenbergii (Palaemonidae) in cultured pond
}

\author{
Thanya Reunura ${ }^{1}$, Taeng On Prommi ${ }^{\text {Corresp. } 1}$ \\ ${ }^{1}$ Department of Science, Kasetsart University, Nakhon Pathom, Nakhon Pathom, Thailand \\ Corresponding Author: Taeng On Prommi \\ Email address: faastop@ku.ac.th
}

Background. The presence of plastic particles in freshwater species is becoming a global concern owing to the potential impact on food security and human health. In this study, we investigated the presence microplastics (MPs) in two economically important freshwater species, the giant freshwater prawn (Macrobrachium rosenbergii) and the white leg shrimp (Litopenaeus vannamei) cultured in a polyculture pond in the central part of Thailand. Methods. The gastrointestinal tract (GT) of 300 giant freshwater prawn (160 female and 140 male) and 150 white leg shrimp specimens were investigated for the presence of MPs. Results. From the pooled samples, a total of 1,166 MP items were identified. Specifically, the GTs of female and male freshwater prawns and white leg shrimps contained an average of $33.31 \pm 19.42,33.43 \pm 19.07$, and $11.00 \pm 4.60 \mathrm{MP}$ items per individual, respectively. Further, their mean MP contents per $g$ of gut material were $32.66 \pm 5.10$, $32.14 \pm 4.85$, and $10.28 \pm 1.19$ MP items, respectively.In the GT if these species, MPs with sizes in the range 500-1000 $\mu \mathrm{m}$, were predominant, and white/transparent MPs were most prevalent (63.67\%). Furthermore, regarding the morphotypes of the MPs, fibers, fragments, films, and spheres were frequently observed, with fibers shows predominance. Specifically, the proportions of fibers in the GTs of female Macrobrachium rosenbergii, male Macrobrachium rosenbergii, and Litopenaeus vannamei were 83.3, 79.91, and $46.06 \%$, respectively. Four MP polymer types, polyethylene, polycaprolactone, polyvinyl alcohol, and acrylonitrile butadiene styrene, were also identified via FTIR spectroscopy, which further confirmed the presence of MPs in the GT of the freshwater-cultured species. Discussion. Our findings indicated that consuming shrimps and prawns without first removing the MPs from their GTs is one of the mean by which humans get exposed to MPs. Thus, MPs in freshwater species can be passed down the food chain to humans. 
1 Detection of microplastics in Litopenaeus vannamei (Penaeidae) and Macrobrachium

2 rosenbergii (Palaemonidae) in cultured pond

3 Thanya Reunura, Taeng On Prommi

4 Department of Science, Faculty of Liberal Arts and Science, Kasetsart University, Kamphaeng

5 Saen Campus, Nakhon Pathom Province, 73140, Thailand

6 Corresponding author:

7 Taeng On Prommi

8 Department of Science, Faculty of Liberal Arts and Science, Kasetsart University, Kamphaeng

9 Saen Campus, Nakhon Pathom, 73140, Thailand

10 Email address: faastop@ku.ac.th 


\section{Abstract}

Background. The presence of plastic particles in freshwater species is becoming a global concern owing to the potential impact on food security and human health. In this study, we investigated the presence microplastics (MPs) in two economically important freshwater species, the giant freshwater prawn (Macrobrachium rosenbergii) and the white leg shrimp (Litopenaeus vannamei) cultured in a polyculture pond in the central part of Thailand.

Methods. The gastrointestinal tract (GT) of 300 giant freshwater prawn (160 female and 140 male) and 150 white leg shrimp specimens were investigated for the presence of MPs.

Results. From the pooled samples, a total of 1,166 MP items were identified. Specifically, the GTs of female and male freshwater prawns and white leg shrimps contained an average of 33.31 $\pm 19.42,33.43 \pm 19.07$, and $11.00 \pm 4.60 \mathrm{MP}$ items per individual, respectively. Further, their mean MP contents per $\mathrm{g}$ of gut material were $32.66 \pm 5.10,32.14 \pm 4.85$, and $10.28 \pm 1.19 \mathrm{MP}$ items, respectively. In the GT if these species, MPs with sizes in the range 500-1000 $\mu \mathrm{m}$, were predominant, and white/transparent MPs were most prevalent (63.67\%). Furthermore, regarding the morphotypes of the MPs, fibers, fragments, films, and spheres were frequently observed, with fibers shows predominance. Specifically, the proportions of fibers in the GTs of female Macrobrachium rosenbergii, male Macrobrachium rosenbergii, and Litopenaeus vannamei were $83.3,79.91$, and $46.06 \%$, respectively. Four MP polymer types, polyethylene, polycaprolactone, polyvinyl alcohol, and acrylonitrile butadiene styrene, were also identified via FTIR spectroscopy, which further confirmed the presence of MPs in the GT of the freshwater-cultured species.

Discussion. Our findings indicated that consuming shrimps and prawns without first removing the MPs from their GTs is one of the mean by which humans get exposed to MPs. Thus, MPs in freshwater species can be passed down the food chain to humans.

\section{Introduction}

Plastic pollution is a serious issue that endangers species in aquatic ecosystems as well as human health. Microplastics (MPs), in particular, with length in the order of $<5 \mathrm{~mm}$ (NOAA, 2016), are formed as a result of the fragmentation of larger plastic debris or are purposefully designed to be that size for commercial purposes (Arthur et al., 2009). Based on their origin, they can be classified as primary and secondary MPs (Masura et al., 2015). Specifically, primary MPs are those with diameter $<5 \mathrm{~mm}$ at manufacture, whereas secondary MPs are those formed from the degradation of larger pieces of plastics over time owing to processes, such as UV radiation or photo-oxidative degradation (GESAMP, 2015, Masura et al., 2015). Further, MPs have different colors, sizes, and shapes (Wright et al., 2013), and some of the most frequently observed MP shapes are the fiber, film, fragment, and granule shapes (Rocha-Santos \& Duarte, 2017). Owing to these differences in size and shape, MPs have varying densities (Wright et al. 2013). The less dense ones float on the water surface, the denser ones may be suspended within the water column, while the much denser ones may sink to the bottom of the water column (Wright et al., 2013). It has also been reported that lighter particles may become denser over time as a variety of chemical substances and microorganisms adhere to their surface (Avio et al., 2017) given that 
owing to their high surface-to-volume ratio as well as their hydrophilic nature, they have a high affinity for different chemical substances and microorganisms (Carbery et al., 2018). This increases their densities over time; thus, they eventually sink into sediments (Avio et al., 2017).

Plastic particles can move from land-based sources to streams and rivers owing to the action of wind, rain, waste water flow, and inappropriate plastic waste disposal (Duis \& Coors, 2016). Thus, owing to their small size, they are widely distributed in the environment and can enter the human body as well as other organisms via ingestion and inhalation, causing negative effects. Additionally, their small size allows them to be bioavailable for ingestion by aquatic biota, and reportedly, their bioavailability increases as their size decreases (Carbery et al., 2018). Reportedly, the presence of particles at all levels of the water column also increases their bioavailability to all types of aquatic biota, from filter feeders to deposit feeders, and from small primary consumers, like zooplankton, to top predators, like sharks (Avio et al., 2017, Carbery et al., 2018). Thus, MP ingestion can occur directly from water or sediments, as is the case with filter feeders and deposit feeders or indirectly via transfer through food chains (Herrera et al., 2019; Wang et al., 2019). Reportedly, the accumulation of MPs in the digestive tracts of living organisms causes internal wounds and also clogs the digestive tract of these organisms, giving a false sense of hunger satiation (Wright et al., 2013; Rocha-Santos \& Duarte, 2017), and this often leads to a decrease in foot intake or its complete inhibition, resulting in malnutrition and subsequently, death (Rocha-Santos \& Duarte, 2017).

Aquatic organisms, particularly fish and shellfish, are vulnerable to MP ingestion owing to the appealing color of the MPs as well as their buoyancy, which resembles that of their food. It has also been observed that MPs can enter the food chain following the consumption of contaminated seafood or food products, and this endangers human health (Wright \& Kelly, 2017; Rist et al., 2018; Su et al., 2019). Generally, ingestion is regarded as the primary route by which aquatic organisms, such as fish, shellfish, and shrimp take up MPs (Sanchez et al., 2014; Lusher et al., 2013; Vandermeersch et al., 2015), and reportedly, these MPs reside in the gut or intestinal tract after ingestion and are eventually eliminated (Rummel et al., 2016; Welden \& Cowie, 2016). Physical damage owing to MP ingestion, including internal and/or external abrasions, ulcers, and digestive tract blockages, has also been reported (Wright et al., 2013). While some ingested contaminants may accumulate in tissues and cause internal exposure, MP exposure is more transient in nature.

Shrimps, which are bottom water column dwellers, eat small crustaceans, mud, detritus, vegetable matter, and diatoms (Smith et al., 1992). Given that MPs are the same size as sediments and planktonic prey items for lower trophic organisms, the possibility of their ingestion by benthic and pelagic biota, with diverse feeding behaviors, increases as the density of MPs in water increases (Wright et al., 2013). Further, the presence of MPs in shrimps in various geographical regions of the world has been previously reported in several studies (Devriese et al., 2015; Abbasi et al., 2018; Carreras-Colom et al., 2018; Akhbarizadeh et al., 2019; Cau et al., 2019; Curren et al., 2020; Daniel et al., 2020; Hossain et al., 2020; Nan et al., 2020; Gurjar et al., 2021). In this study, shrimps were chosen because they play an important role in the food chain and provide food for a variety of animals, ranging from fish to humans. Further, to the best of our knowledge, no study has been conducted to investigate the presence of MPs in shrimps or prawns reared in inland water ponds, Therefore, in this study, we investigated the presence of microplastics in two freshwater-cultured species (Litopenaeus vannamei and Macrobrachium rosenbergii), which are popular foods in both domestic and international markets. 
114 Materials \& Method

115 Sample collection and processing

116 Fresh specimens of the two freshwater organisms, the giant freshwater prawn

117 (Macrobrachium rosenbergii) and the white leg shrimp (Litopenaeus vannamei), were obtained

118 directly from three local shrimp polyculture ponds in the central region of Thailand using the

119 modified seine net on October 20, 2020.

120 In total, 300 giant freshwater prawn (160 females and 140 males) and 150 white leg shrimp

121 specimens were collected, after which they were kept cold in an icebox before transportation to

122 the Zoology Laboratory of the Faculty of Liberal Arts and Science (Kasetsart University,

123

124

125

126

127

128

129

130

131

132

133

134

135

136

137

138

139

140

141

142

143

144

145

146

147

148

149

150

151

152

153

154

155

156

157

158

159 Kamphaeng Saen Campus, Nakhon Pathom Province, Thailand). In the lab, the specimens were stored at $-20^{\circ} \mathrm{C}$ until analysis. Specifically, before analysis, the frozen specimens were defrosted in a metal tray and rinsed twice with deionized water (DI). Thereafter, their body weights were measured and documented, and 10 male giant freshwater prawns (x 14 replicates), 10 female giant freshwater prawns (x 16 replicates), and 15 white leg shrimp (x 15 replicates) with identical weights were grouped to for the analysis of MP ingestion. Metal forceps and metal scissors, which were cleaned with DI after each batch of specimens were processed, were used to individually dissect the specimens on metal trays and remove their gastrointestinal tracts (GTs), respectively. The GTs were then transferred into $100-\mathrm{mL}$ glass beakers and weighted.

To prevent any form of MP contamination, all the lab surfaces and glassware were thoroughly cleaned using $70 \%$ ethanol and ultrapure water before commencing the lab work. Further, to prevent MP cross-contamination between the specimens, the forceps were carefully rinsed after the removal of the GTs from each specimen. Finally, to prevent airborne MP contamination, the Petri dishes containing the GTs were immediately covered with aluminum foil.

\section{Hydrogen peroxide treatment}

MPs were extracted from the GTs of the specimens using a $30 \% \mathrm{H}_{2} \mathrm{O}_{2}$ solution. To break down the soft tissue, $20 \mathrm{~mL}$ of $30 \% \mathrm{H}_{2} \mathrm{O}_{2}$ was added to each of the glass beakers (Avio, Gorbi \& Regoli, 2015), which thereafter, were wrapped in parafilm and shaken at $150 \mathrm{rpm}$ for 7 days, until all of the organic matter was digested. The blanks were run parallel to the soft tissue disintegration and scanned for the presence of MPs. Thus, no parafilm or MP particles were detected in the blanks.

\section{Potassium formate floatation and filtration}

MPs were separated from the dissolved organic matter solution via $\mathrm{HCO}_{2} \mathrm{~K}$ flotation and filtration (Zhang et al., 2016). Each sample was placed in a glass separation funnel and saturated with $\mathrm{HCO}_{2} \mathrm{~K}(99 \%)$ until the solution reached $1.6 \mathrm{~g} \mathrm{ml}^{-1}$. Thereafter, the samples were maintained at room temperature for at least $3 \mathrm{~h}$. The saturated solution allowed the less dense particles to separate, resulting in a layer of MPs floating upwards, while undissolved organic leftovers and inorganic materials sank to the bottom of the glass containers. The samples were then filtered using a nylon membrane filter (pore size, $0.45 \mu \mathrm{m}$; diameter, $47 \mathrm{~mm}$; Whatman, Kent, UK) with a pressure filtration device. After this step, each membrane filter was placed in a clean Petri dish, covered with aluminum foil, and dried for 2 days at $50{ }^{\circ} \mathrm{C}$ in a drying cabinet.

A stereomicroscope (Leica EZ4E) was used to visually analyze each filter for the presence of MPs, which were identified based on their color and shape (Hidalgo-Ruz et al., 2012). Further, the shapes of the MPs were classified as fiber, sphere, film (thin and small layer), or fragment (part of a larger plastic item) (Su et al., 2018). 
160

161

162

163

164

165

166

167

168

169

170

171

172

173

174

175

176

177

178

179

180

181

182

183

184

185

186

187

188

189

190

191

192

193

194

195

196

197

198

199

200

201

202

203

204

\section{FTIR analyses of MPs found in the GT of the specimens}

A Hyperion 2000 FT-IR microscope equipped with a mercury-cadmium telluride detector (Bruker Daltonik, Billerica, MA, USA) was used to manually evaluate 20 particles from the GT of the specimens at wavenumbers in the range $4000-600 \mathrm{~cm}^{-1}$, with 32 co-added scans and at a spectral resolution of $4 \mathrm{~cm}^{-1}$. OPUS software version 7.5 (Bruker) was used to compare the collected spectra to those in the Bruker database. Only particles with a hit quality threshold $>$ 700 were designated MPs, as previously described (Bergmann et al., 2017).

\section{Data analysis}

The MP type, size, and color were analyzed and measured for each shrimp and prawn. Pooled samples of 10 male giant freshwater prawns (14 replicates), 10 female giant freshwater prawns (16 replicates), and 150 white leg shrimp specimens (15 replicates) were used to calculate the average number of MPs per $g$ of the GT. One-way ANOVA in combination with Tukey's (HSD) post hoc pairwise comparisons was performed to determine significant differences in the abundance of the MPs in the shrimp and prawn species using SPSS software version 20.0 (IBM, Armonk, NY, USA). Further, to generate graphs, Microsoft Excel 2013 (Microsoft Corp., Redmond, WA, USA).

\section{Results}

\section{Abundance of MPs}

A total of 300 giant freshwater prawn (160 female and 140 male) and 150 white leg shrimp specimens were examined. Our analysis confirmed the presence of MP in both female and male giant freshwater prawns (Macrobrachium rosenbergii) as well as white leg shrimps (Litopenaeus vannamei) (Table 1).

Female and male $M$. rosenbergii weighed $23.71 \pm 4.72$ and $59.32 \pm 7.64$ g, respectively, while L. vannamei weighed $20.78 \pm 3.99 \mathrm{~g}$ (Table 1). Further, a total of 533 (range, 11-74), 468 (range, 12-72), and 165 (range, 4-23) MP items were observed in the 45 replicates of pooled samples from female and male $M$. rosenbergii and L. vannamei, respectively, and the average number of MP items per individual for these three specimens were of 33.31 $\pm 19.42,33.43 \pm$ 19.07 , and $11.00 \pm 4.60$, respectively.

Furthermore, the MPs in the GT of female and male M. rosenbergii and L. vannamei were $32.66 \pm 5.10,32.14 \pm 4.85$, and 10.28 $\pm 1.19 \mathrm{MP}$ items/g GT, respectively (wet weight). Based on one-way ANOVA, our analysis also showed significant differences between the total number of MP items corresponding to the different specimens $(F=9.838 ; p=0.000)$ (Table 1$)$.

\section{MP sizes}

Figure 1 shows the size class frequency distribution of the MPs in the acid digested GTs of the specimens. The identified MPs could be grouped into four different size ranges: $<250 \mu \mathrm{m}$, 250-500 $\mu \mathrm{m}, 500-1000 \mu \mathrm{m}$, and 1000-5000 $\mu \mathrm{m}$, and in all the specimens, MPs corresponding to all the four size categories were observed.

The GT of female $M$. rosenbergii predominantly contained large-size MPs $(500-1000 \mu \mathrm{m}$; $54 \%, 289$ items), whereas MPs with sizes in the ranges $250-500 \mu \mathrm{m}, 1000-5000 \mu \mathrm{m}$, and $<250$ $\mu \mathrm{m}$ constituted 31\% (165 items), 8\% (42 items), and 7\% (36 items) of the MPs in this species, respectively.

Peer) reviewing PDF | (2021:10:67034:3:0:NEW 16 Jan 2022) 
In the GT of male $M$. rosenbergii, large-size MPs (500-1000 $\mu \mathrm{m})$ were also predominant (54\%, 255 items), while MPs with sizes in the ranges $<250 \mu \mathrm{m}, 250-500 \mu \mathrm{m}$, and $1000-5000$ $\mu \mathrm{m}$ constituted $23 \%$ (106 items), 15\% (69 items), and 8\% (38 items) of the MPs in this specimen, respectively.

Further, in the GT of $L$. vannamei, all four MP size categories: $<250 \mu \mathrm{m}, 500-1000 \mu \mathrm{m}$, $250-500 \mu \mathrm{m}$, and $1000-5000 \mu \mathrm{m}$, with proportions $38 \%$ (63 items), 37\% (61 items), $15 \%$ (25 items), and 10\% (16 items), respectively, were observed. Additionally, L. vannamei had a higher proportion of smaller MPs, possibly owing to its smaller size (i.e., $20.78 \pm 3.99 \mathrm{~g}$ ) compared with male $M$. rosenbergii $(59.32 \pm 7.64 \mathrm{~g})$. Thus, MP size proportion distribution was significantly affected by the species investigated $\left(\chi^{2}=124.766 ; \mathrm{df}=6 ; \mathrm{p}=0.000\right)$.

\section{MP type and color}

Fiber-, fragment-, film-, and sphere-shaped MPs, which differed in proportion between the specimens $\left(\chi^{2}=116.396 ; \mathrm{df}=6 ; \mathrm{p}=0.000\right)$, were observed in the GT of the different specimens (Table 2).

Fiber MPs $(83.3 \%)$ showed dominance in the GT of female $M$. rosenbergii, followed by fragment MPs (16.33\%) and sphere MPs (0.38\%). No film MPs were observed. Conversely, in the GT of male M. rosenbergii, all four MP types were observed, with fiber MPs showing predominance $(79.91 \%)$ followed by fragment $(16.67 \%)$, film (2.99\%), and sphere $(0.43 \%)$ MPs. Further, in the GT of L. vannamei, fiber also showed dominance (46.06\%), followed by fragment $(45.45 \%)$, and film $(8.48 \%)$ MPs, while sphere MPs were absent. Figure 2 shows a variety of MPs of different shapes, colors, and sizes.

The MPs observed had six distinct colors, the most prevalent of which was white (transparent) MPs, followed by black, yellow, blue, red, and green MPs. In the GT of male $M$. rosenbergii and L. vannamei, all six MP colors were observed, whereas in the GT of female $M$. rosenbergii, green MP particles were absent (Table 2). Additionally, the MP color proportions differed significantly between the specimens $\left(\chi^{2}=83.938 ; \mathrm{df}=10 ; \mathrm{p}=0.000\right)$.

\section{MP polymer types}

Based on FT-IR analysis, 16 of the 20 randomly selected particles were identified as plastic material, while 4 were identified as non-plastic material, and of the 16 MP particles, 13 were polyethylene (65\%), while 3 others were identified as polycaprolactone, polyvinyl alcohol, and acrylonitrile-butadiene-styrene polymers ( $5 \%$ each) (Table 3). The FT-IR spectra further showed peaks at 2900 and $1500 \mathrm{~cm}^{-1}, 2950$ and $1250 \mathrm{~cm}^{-1}, 3350$ and $2900 \mathrm{~cm}^{-1}$, and 2900 and $1500 \mathrm{~cm}^{-1}$ corresponding to polyethylene, polycaprolactone, polyvinyl alcohol, and acrylonitrile-butadienestyrene showed peaks, respectively (Fig. 3).

\section{Discussion}

In this study, we confirmed the presence of MPs in the GTs of M. rosenbergii and $L$. vannamei, both of which are usually sold fresh in Thai markets, and also exported to other countries. Despite the fact that MPs are a well-known pollutants in freshwater, their presence in shrimps cultured in ponds has not been previously documented. Thus, to the best of our knowledge, this study is the first to demonstrate the presence of MPs in freshwater shrimps.

The average abundances of MPs in the GT of male and female M. rosenbergii were $32.14 \pm$ 4.85 and $32.66 \pm 5.10$ items/g of GT, respectively. Further, in the GT of L. vannamei, their average abundance was $10.28 \pm 1.19 \mathrm{items} / \mathrm{g}$ GT. Therefore, these species, which have high 
251

commercial value and are frequently consumed by humans, contain varied proportions of MPs, which they obtained predominantly via ingestion. This is consistent with reports of contamination in species from various climatic regions (Table 4). However, the abundances here reported are higher than those reported recently by Hossain et al. (2020), who identified a total of 39 and $33 \mathrm{MP}$ items in M. monoceros and P. monodon from the coastal waters of Bangladesh, respectively, with average abundances of $3.87 \pm 1.05$ and $3.40 \pm 1.23 \mathrm{MP}$ items $/ \mathrm{g} \mathrm{GT}$, respectively. In an earlier study, they observed an average value of $0.68 \pm 0.55 \mathrm{MP} / \mathrm{g}(1.23 \pm$ $0.99 \mathrm{MPs} /$ shrimp) for brown shrimps from the Channel area and the southern part of the North Sea (Devriese et al., 2015). Further, in another previous study, MPs were observed in commercially important crustacean species collected from four different sites in the Musa Estuary and one site in the Persian Gulf. In this study, different forms of MPs were frequently detected in P. semisulcatus (Abbasi et al., 2018). A study involving the brown shrimp, Crangon crangon, from the southern North Sea and the English Channel reported similar findings; MPs were observed in the guts of $63 \%$ of the shrimps (Devriese et al., 2015). The presence of MPs was also confirmed in $36 \%$ of the Australian glass shrimp, Paratya australiensis (Family Atyidae), which is found in fresh waterbodies in eastern Australia (Nan et al., 2020). However, it is remarkable that in this study, all the specimens investigated (100\%), which were both cultured in a freshwater pond, contained more ingested MPs. This could be because the shrimp meal, water, or prawn fishing gear represent a potential source of MPs that can be transferred to the cultured shrimps, thus posing a concern for aquaculture (Hanachi et al., 2019). The findings of this study indicate that shrimps and prawns cultured in ponds are not MP pollutant free.

Based on size, in this study, we classified MPs under four different size groups, i.e., $<250$ $\mu \mathrm{m}, 250-500 \mu \mathrm{m}, 500-1000 \mu \mathrm{m}$, and 1000-5000 $\mu \mathrm{m}$ (Fig. 1). Thus, we observed that MPs, with sizes in the range 500-1000 $\mu \mathrm{m}$, were most abundant in the examined specimens. In a previous study, it was observes that shrimps inhabiting shallow water habitats of the Channel area of the Southern North Sea contain MPs with sizes in the range 200-1000 $\mu \mathrm{m}$ in their GTs (Devriese et al., 2015). In this present study, the GT of female and male $M$. rosenbergii predominantly contained large-size (500-1000 $\mu \mathrm{m})$ MPs (54\%), while the GT of L. vannamei showed a lower proportion of large size MPs (37\%). This observation can be attributed to the fact that $L$. vannamei has a smaller mouth aperture than $M$. rosenbergii. Thus, its GT was predominated by smaller MPs (Gurjar et al., 2021). Hossain et al. (2020) found that $70 \%$ of the MPs in the GT of tiger shrimps are larger-size fractions $(1-5 \mathrm{~mm})$ compared with those in the GT of brown shrimps, in whose GT, smaller MPs $(<1000 \mu \mathrm{m})$ are predominant $(83 \%)$. Thus, the sizes of the ingested MPs varies according to species and sampling location. Specifically, Carreras-Colom et al. (2018) observed that Aristeus antennatus, a deep-water shrimp collected from the northwestern Mediterranean Sea, has 13 potential plastic items in its stomach, with fibers having length and widths in the ranges $1.9-26.7 \mathrm{~mm}$ (median $6.6 \mathrm{~mm}$ ) and $0.012-0.032 \mathrm{~mm}$, respectively.

In this study, we observed that the GT of the pooled specimens predominantly consisted of fiber MPs (69.67\%), followed by fragment, film, and sphere MPs. Additionally, fiber MPs were observed in the GT of $83.3 \%$ of female $M$. rosenbergii, $79.91 \%$ of male $M$. rosenbergii, and $46.06 \%$ of L. vannamei. This high proportion of fiber MPs in the GT of the specimens could be attributed to intense shrimp feeding as well as the anthropogenic activities in the study area. Reportedly, fibers constitute the most abundant type MP pollution in marine waters worldwide (Walkinshaw et al., 2020). Our findings and observations are consistent with those of 
297 previous studies involving decapod crustaceans (Murray \& Cowie, 2011), blue mussels (De 298 Witte et al., 2014), and brown shrimps (Devriese et al., 2015), which showed overall fiber MP 299 predominance in the guts of these species. Hossain et al. (2020) identified fiber MPs as 300 predominant in P. monodon (57\%), followed by particles (29\%) and fragments (14\%), while 301 brown shrimps, were predominated by MP particles (42\%), followed by fibers (32\%), and 302 fragments (26\%). Further, Nan et al. (2020) reported that fiber-shaped MPs are the most 303 frequently observed MPs in the GT of shrimps collected from Australian waters, and in the gut 304 of the deep water shrimp, A. antennatus, Carreras-Colom et al. (2018) noted the absence of film305 like MP particles. In another study involving brown shrimps from the Channel area and the synthetic fibers $(96.5 \%)$. The plastic and film granules were relatively small-sized $(20-100 \mathrm{~mm})$ (Devriese et al., 2015). Further, Abbasi et al. (2018) reported that almost all the MPs ingested by prawns netted from the Musa Estuary in the Persian Gulf were filamentous fragments, containing single fibers of varying sizes. The results of this study corroborate those of previous studies given that fibers were the most frequently observed form of MP in the GT of the pond-cultured specimens investigated in this study. Furthermore, in this study, fragment MPs were found to be abundant (16-45\%) in both shrimps and prawns. This is consistent with observations made by Devriese et al. (2015) and Murray \& Cowie (2011) regarding brown shrimps and decapod crustaceans, respectively.

Additionally, in this study, white (transparent), black, yellow, blue, red, and green colored MPs were observed in the GT of all the specimens, with the white (transparent) MPs showing predominance (63.67\% of all the MPs). Generally, MP particles can be consumed directly owing to their morphological similarity to natural food items, or indirectly owing to their adherence to food particles, and given that they are visually similar to the natural foods and preys of shrimps, their bioavailability to these organisms is relatively high (Ory et al., 2017). Similar MP color patterns have been observed in tiger and brown shrimps collected from Bangladesh waters. In this previous study, black MPs were most frequently observed, followed by transparent (white), green, blue, and red MPs. In the gut of P. monodon's, MPs of five different colors have been observed (black, white, green, blue, and red with relative abundances of 48, 33, 11, 6, and 2\%, respectively); however, $M$. monoceros showed a slightly different MP color pattern colors (Hossain et al., 2020). In shrimps from Australian waters, blue colored MPs were most frequently observed (90\%) (Nan et al. 2020). Further, in the deep-water shrimp, A. antennatus, five different fiber colors (transparent, blue, black, red, and green) have been observed with no particular color showing predominance (Carreras-Colom et al., 2018). Further, Abbasi et al. (2018) reported that the gut of $P$. semisulcatus predominantly contains black or grey MP filaments $(71 \%)$. It has also been reported that the brown shrimp, C. crangon, primarily ingests yellow-greenish MPs (50\%) followed by purple-blue (43\%), translucent $(15 \%)$, and orange $(12 \%)$ fiber MPs, with a small fraction of transparent (8\%) and pink (2\%) fibers. Possibly, translucent fibers result from colored fibers owing to exposure to acids during the acid treatment process (Devriese et al., 2015). Similar to our findings, the presence of MPs of various colors in various pelagic and demersal fishes has also been confirmed (Berger et al., 2010; Lusher et al., 2013; Belles et al., 2016; Ory et al., 2017; Gurjar et al., 2021).

Based on FT-IR, we identified four types of MP polymers (polyethylene, polycaprolactone, polyvinyl alcohol, and acrylonitrile-butadiene-styrene) in the GT of the examined 
specimens. These polymers are widely used in the manufacture of fishing equipment and ropes as well as food packaging and clothing materials (Cheung et al., 2018; Wang et al. 2019). Similar to our findings, Gurjar et al. (2021) reported the presence of polyethylene, polypropylene, polyamide, nylon, polyester, and polyethylene terephthalate in the GT of $M$. monoceros, $P$. stylizer, and $P$. indices. Further, in P. australiensis collected in Australia, 11 different types of MP polymers were observed, with rayon and polyester showing predominance (22.6 and 7.5\%, respectively) (Nan et al., 2020). Polymer analysis in a recent study by Gurjar et al. (2021) confirmed that laundry and domestic wastewater, fishing gear, and food packaging materials could be the primary source of MP pollution in the study area. Therefore, in this study, the MPs in the GTs of shrimps and prawns, which is a serious issue with respect to aquaculture, possibly originated from shrimp meal, water, or prawn fishing gear (Hanachi et al., 2019).

MPs have been observed in aquatic organisms, raising concerns regarding their effect on human health (Sharma \& Chatterjee, 2017; Smith et al., 2018). Further, it has been observed that the consumption of MPs by shrimps results in digestive organ damage as well as a decrease in growth and reproductive output. Usually, shrimps are peeled to get rid of the head and shell before consumption. However, given that their GTs are not always entirely eliminated during their preparation, the MPs in their intestines could be passed to humans following consumption. This is a route of human exposure to MPs that is frequently considered in terms of human health and food security (Cox et al., 2019). Lassen et al. (2015) indicated that ingested MP from toothpaste can be absorbed by the human GT, and a recent study confirmed the presence of MPs in human colectomy specimens (Ibrahim et al., 2020). However, there is no published research on the destiny of MPs resulting from human consumption of shrimps and prawns. Thus, further research is needed to determine the retention and impact of MPs from shrimps and prawns on human health.

\section{Conclusion}

In this study, our findings confirmed the presence of MPs of various shapes, sizes, and colors in shrimps and prawns harvested from a freshwater ponds in the central region of Thailand. Possibly, the MPs originated from shrimp meal, water, or prawn fishing gear (possible primary sources). Additionally, the use of FT-IR analysis to characterized the MPs observed in the examined species further enhanced the reliability of our results. By removing the intestine completely before cooking and eating, MP contamination in the edible portion of shrimps can be attenuated. Therefore, the health risks associated with MP-contaminated shrimps can be mitigated to some extent. Nevertheless, further studies are needed to investigate the accumulation of plastic debris on other edible parts of shrimps. Further, it is also necessary to clarify the potential for pollutant transfer to higher trophic levels and also investigate potential measures that can be taken to protect aquatic species from plastic pollution.

\section{References}

Abbasi S, Soltani N, Keshavarzi B,Moore F, Turner A, Hassanaghaei M. 2018. Microplastics in different tissues of fish and prawn from the Musa Estuary. Persian Gulf, Chemosphere 205, 80-87 DOI 10.1016/j.chemosphere.2018.04.076

Akhbarizadeh R, Moore F, Keshavarzi B. 2019. Investigating microplastics bioaccumulation and biomagnification in seafood from the Persian Gulf: a threat to human health? Food Additives 
\& Contaminants: Part A: Chemistry, Analysis, Control, Exposure \& Risk Assessment 36, 16961708 DOI 10.1080/19440049.2019.1649473

Arthur C, Baker JE, Bamford HA. 2009. Proceedings of the International Research Workshop on the Occurrence, Effects, and Fate of Microplastic Marine Debris, September 9-11, 2008. University of Washington Tacoma, Tacoma, WA, USA.

Avio CG, Gorbi S, Regoli F. 2017. Plastics and microplastics in the oceans: From emerging pollutants to emerged threat. Marine Environmental Research 128, 2-11 DOI 10.1016/j.marenvres.2016.05.012

Avio CG, Gorbi S, Regoli F. 2015. Experimental development of a new protocol for extraction and characterization of microplastics in fish tissues: first observations in commercial species from Adriatic Sea. Marine Environmental Research 111, 18-26

DOI 10.1016/j.marenvres.2015.06.014

Bellas J, Martínez-Armental J, Martínez-Camara A, Besada V, Martínez-Gomez C. 2016. Ingestion of microplastics by demersal fish from the Spanish Atlantic and Mediterranean coasts. Marine Pollution Bulletin 109(1), 55-60 DOI 10.1016/j.marpolbul.2016.06.026

Bergmann M, Wirzberger V, Krumpen T, Lorenz C, Primpke S, Tekman MB, Gerdts G. 2017. High quantities of microplastic in Arctic deep-sea sediments from the HAUSGARTEN Observatory. Environmental Science and Technology 51, 11000-11010 DOI 10.1021/acs.est.7b03331

Boerger CM, Lattin GL, Moore SL, Moore CJ. 2010. Plastic ingestion by planktivorous fishes in the North Pacific Central Gyre. Marine Pollution Bulletin 6, 2275-2278 DOI 10.1016/j.marpolbul.2010.08.007

Carbery M, O'Connor W, Thavamani P. 2018. Trophic transfer of microplastics and mixed contaminants in the marine food web and implications for human health Environment International 115, 400-409 DOI 10.1016/j.envint.2018.03.007 Carreras-Colom E, Constenla M, Soler-Membrives A, Cartes JE, Baeza M, Padrós F, Carrassón M. 2018. Spatial occurrence and effects of microplastic ingestion on the deep-water shrimp Aristeus antennatus. Marine Pollution Bulletin 133, 44-52

DOI 10.1016/j.marpolbul.2018.05.012

Cau A, Avio CG, Dessì C, Follesa MC,Moccia D, Regoli F, Pusceddu A. 2019. Microplastics in the crustaceans Nephrops norvegicus and Aristeus antennatus: flagship species for deep-sea environments? Environmental Pollution 255, 113107 DOI 10.1016/j.envpol.2019.113107 Cheung LTO, Lui CY, Fok L. 2018. Microplastic Contamination of Wild and Captive Flathead Grey Mullet (Mugil cephalus). International Journal of Environmental Research and Public Health 15, 597 DOI 10.3390/ijerph15040597

Cox KD, Covernton GA, Davies HL, Dower JF, Juanes F, Dudas SE. 2019. Human consumption of microplastics. Environmental Science \& Technology 53, 7068-7074 DOI 10.1021/acs.est.9b01517

Curren E, Leaw CP, Lim PT, Leong SCY. 2020. Evidence of marine microplastics in commercially harvested seafood. Frontiers in Bioengineering and Biotechnology 8, 562760 DOI $10.3389 /$ fbioe. 2020.562760

Daniel DB, Ashraf PM, Thomas SN. 2020. Abundance, characteristics and seasonal variation of microplastics in Indian white shrimps (Fenneropenaeus Indicus) from coastal waters off Cochin, Kerala, India. Science of the Total Environment 737, 139839 DOI 10.1016/j.scitotenv.2020.139839 
434 De Witte B, Devriese L, Bekaert K, Hoffman S, Vandermeersch G, Cooreman K, Robbens

435 J. 2014. Quality assessment of the blue mussel (Mytilus edulis): comparison between

436 commercial and wild types. Marine Pollution Bulletin 85, 146-155

437 DOI 10.1016/j.marpolbul.2014.06.006

438 Devriese LI, Van Der Meulen MD, Maes T, Bekaert K, Paul-Pont I, Frere L, Robbens J,

439 Vethaak AD. 2015. Microplastic contamination in brown shrimp (Crangon crangon, linnaeus

440 1758) from coastal waters of the southern North sea and channel area. Marine Pollution Bulletin 441 98, 179-187 DOI 10.1016/j.marpolbul.2015.06.051

442 Gurjar UR, Xavier M, Nayak BB, Ramteke K, Deshmukhe G, Jaiswar AK, Shukla SP.

443 2021. Microplastics in shrimps: a study from the trawling grounds of north eastern part of

444 Arabian Sea. Environmental Science and Pollution Research 28, 48494-48504 DOI

$445 \quad 10.1007 / \mathrm{s} 11356-021-14121-\mathrm{Z}$

446 Hanachi P, Karbalaei S, Walker TR, Cole M, Hosseini SV. 2019. Abundance and properties

447 of microplastics found in commercial fish meal and cultured common carp (Cyprinus carpio).

448 Environmental Science and Pollution Research, 26(23), 23777-23787

449 DOI 10.1007/s11356-019-05637-6

450 Herrera A, Stindlova A, Martinez I, Rapp J, Romero-Kutzner V, Samper M D, Montoto T, 451 Aguiar-Gonzalez B, Packard T, Gomez M. 2019. Microplastic ingestion by Atlantic chub 452 mackerel (Scomber colias) in the Canary Islands coast. Marine Pollution Bulletin 139, 127-135

453 DOI 10.1016/j.marpolbul.2018.12.022

454 Hidalgo-Ruz V, Gutow L, Thompson RC, Thiel M. 2012. Microplastics in the marine 455 environment: a review of the methods used for identification and quantification. Environmental

456 Science and Technology 46, 3060-3075 DOI 10.1021/es2031505

457 Hossain MS, Rahman MS, Uddin MN, Sharifuzzaman SM, Chowdhury SR, Sarker S,

458 Chowdhury MSN. 2020. Microplastic contamination in Penaeid shrimp from the Northern Bay

459 of Bengal. Chemosphere 238, 124688 DOI 10.1016/j.chemosphere.2019.124688

460 Ibrahim YS, Anuar ST, Azmi AA, Khalik WM, Lehata S, Hamzah SR, Ismail D, Ma

461 ZF, Dzulkarnaen A, Zakaria Z, Mustaffa N, Sharif SET, Lee YY. 2020. Detection of

462 microplastics in human colectomy specimens. JGH Open 5(1), 1-6 DOI 10.1002/jgh3.12457

463 Lassen C, Hansen SF, Magnusson K, Noren F, Hartmann NIB, Jensen PR, Nielsen TG,

464 Brinch A. 2015. Microplastics: occurrence, effects and sources of releases to the environment in

465 Denmark. The Danish Environmental Protection Agency. http://www.eng.mst.dk/

466 Lusher AL, McHugh M, Thompson RC. 2013. Occurrence of microplastics in the

467 gastrointestinal tract of pelagic and demersal fish from the English Channel. Marine Pollution

468 Bulletin 67, 94-99 DOI 10.1016/j.marpolbul.2012.11.028

469 Murray F, Cowie PR. 2011. Plastic contamination in the decapod crustacean Nephrops

470 norvegicus (Linnaeus, 1758). Marine Pollution Bulletin 62 (6), 1207-1217

471 DOI 10.1016/j.marpolbul.2011.03.032

472 Masura J, Baker J, Foster G, Arthur C, Herring C. 2015. Laboratory methods for the

473 analysis of microplastics in the marine environment: recommendations for quantifying synthetic

474 particles in waters and sediments (Silver Spring: NOAA) p 31.

475 Nan B, Kellar C, Craig NJ, Keough MJ, Pettigrove V. 2020. Identification of microplastics in

476 surface water and Australian freshwater shrimp Paratya australiensis in Victoria, Australia.

477 Environmental Pollution 259, 113865 DOI 10.1016/j.envpol.2019.113865

478 NOAA, 2016. National Oceanic and Atmospheric Administration. How Much Would it

479 Cost to Clean up the Pacific Garbage Patches. https:/oceanservice.noaa.gov/

Peer] reviewing PDF | (2021:10:67034:3:0:NEW 16 Jan 2022) 
480

podcast/june14/mw126-garbagepatch.html.

Ory NC, Sobral P, Ferreirad JL, Thiel M. 2017. Amberstripe scad Decapterus muroadsi (Carangidae) fish ingest blue microplastics resembling their copepod prey along the coast of Rapa Nui (Easter Island) in the South Pacific subtropical gyre. Science of the Total Environment 586, 430-437 DOI: 10.1016/j.scitotenv.2017.01.175

Rist S, Almroth BC, Hartmann NB, Karlsson TM. 2018. A critical perspective on early communications concerning human health aspects of microplastics. Science of the Total Environment 626, 720-726 DOI 10.1016/j.scitotenv.2018.01.092

Rocha-Santos TAP, Duarte AC. 2017. Characterization and Analysis of Microplastics Comprehensive Analytical Chemistry 75, p 286.

Rummel CD, Adolfsson-Erici M, Jahnke A, MacLeod M. 2016. No measurable "cleaning" of polychlorinated biphenyls from Rainbow Trout in a 9 week depuration study with dietary exposure to $40 \%$ polyethylene microspheres. Environmental Science: Processes \& Impacts 18, 788-795 DOI 10.1039/C6EM00234J

Sanchez W, Bender C, Porcher JM. 2014. Wild gudgeons (Gobio gobio) from French rivers are contaminated by microplastics: Preliminary study and first evidence. Environmental Research 128, 98-100 DOI 10.1016/j.envres.2013.11.004

Sharma S, Chatterjee S. 2017. Microplastic pollution, a threat to marine ecosystem and human health: a short review. Environmental Science and Pollution Research 24, 21530-21547 DOI 10.1007/s11356-017-9910-8

Smith M, Love DC, Rochman CM, Neff RA. 2018. Microplastics in seafood and the implications for human health. Current Environmental Health Reports 5, 375-386 DOI 10.1007/s40572-018-0206-Z

Smith DM, Dall W, Moore LE. 1992. The natural food of some Australian penaeids. In: Proceedings of the Aquaculture Nutrition Workshop (Eds. Allan,G.L.\& Dall,W.), pp. 95- 6. NSWFisheries, Brackish Water Fish Culture Research Station, Salamander Bay, Australia, 1517 April 1991

Su L, Deng H, Li B, Chen Q, Pettigrove V, Wu C, Shi H. 2019. The occurrence of microplastic in specific organs in commercially caught fishes from coast and estuary area of East China. Journal of Hazardous Material 365, 716-724 DOI 10.1016/j.jhazmat.2018.11.024

Su L, Cai H, Kolandhasamy P, Wu C, Rochman CM, Shi H. 2018. Using the Asian clam as an indicator of microplastic pollution in freshwater ecosystems. Environmental Pollution 234, 347-355 DOI 10.1016/j.envpol.2017.11.075

Vandermeersch, G, Van Cauwenberghe L, Janssen CR, Marques A, Granby K, Fait G, Kotterman MJJ, Diogène J, Bekaert K, Robbens J, Devriese L. 2015. A critical view on microplastic quantification in aquatic organisms. Environmental Research 143, Part B, 46-55 DOI 10.1016/j.envres.2015.07.016

Walkinshaw C, Lindeque PK, Thompson R, Tolhurst T, Cole M. 2020. Microplastics and seafood: lower trophic organisms at highest risk of contamination. Ecotoxicology and Environmental Safety 190, 110066-110080 DOI 10.1016/j.ecoenv.2019.110066

Wang W, Gao H, Jin S, Li R, Na G. 2019. The ecotoxicological effects of microplastics on aquatic food web, from primary producer to human: a review. Ecotoxicology and Environmental Safety 173, 110-117 DOI 10.1016/j.ecoenv.2019.01.113 
524 Welden NAC, Cowie PR. 2016. Environment and gut morphology influence microplastic 525 retention in langoustine. Nephrops norvegicus. Environmental Pollution 14, 859-865

526 DOI: 10.1016/i.envpol.2016.03.067

527 Wright SL, Kelly FJ. 2017. Plastic and human health: a micro issue? Environmental Science \& 528 Technology 51, 6634-6647 DOI 10.1021/acs.est.7b00423

529 Wright SL, Thompson RC, Galloway TS. 2013. The physical impacts of microplastics on 530 marine organisms: a review. Environmental Pollution 178, 483-492 DOI

$531 \quad$ 10.1016/j.envpol.2013.02.031

532 Zhang K, Su J, Xiong X, Wu X, Wu C, Liu J. 2016. Microplasticpollution of lakeshore 533 sediments from remote lakes in Tibet plateau, China. Environmental Pollution 219, 450-455

534 DOI 10.1016/j.envpol.2016.05.048

535

536 
Figure 1

Microplastics in shrimp and prawns: sample preparation, digestion, and analytical processes.

L. vannamei Male M. rosenbergii $\square$ Female M. rosenbergii

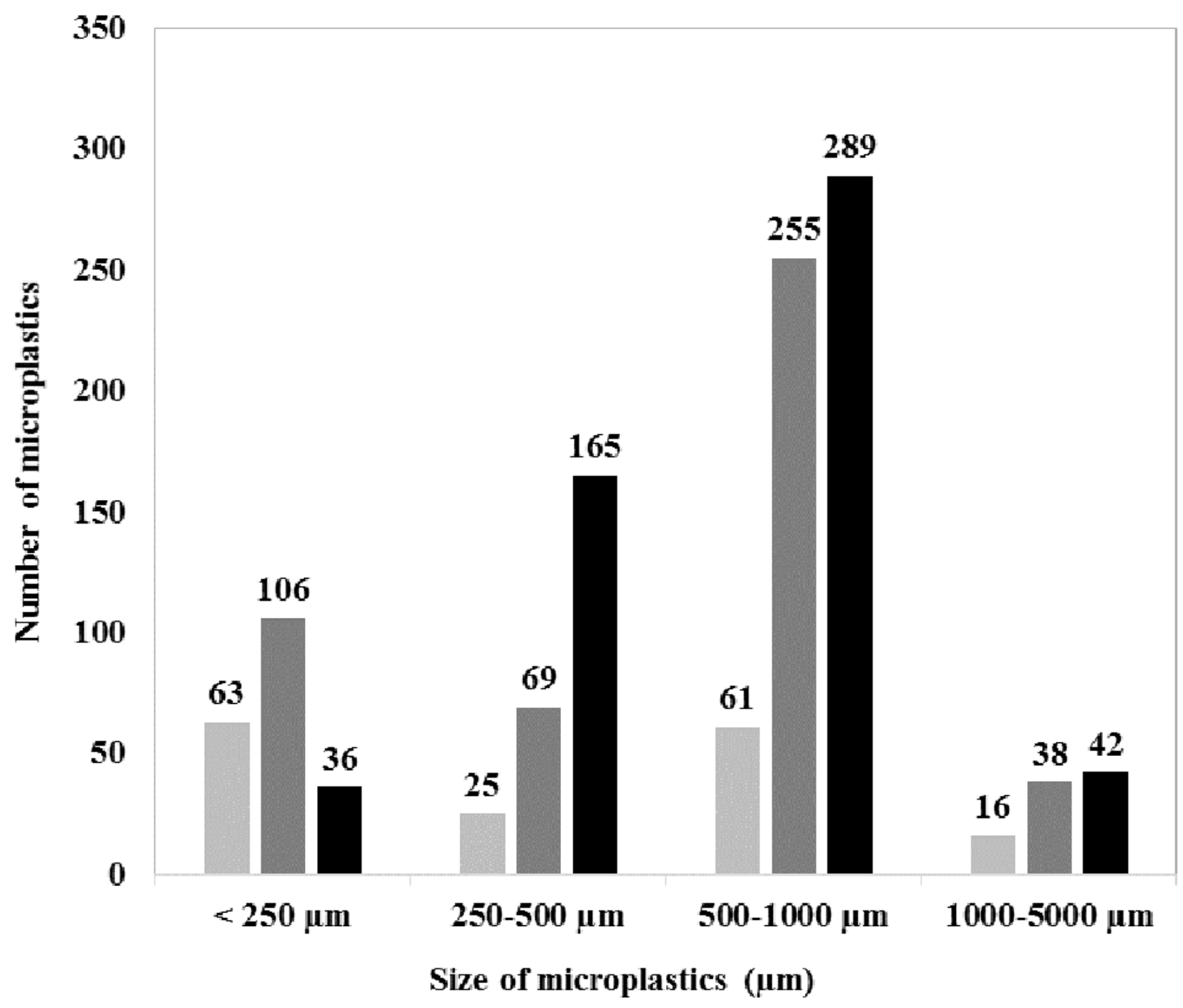


Figure 2

Microplastic size distribution in the gastrointestinal tract of shrimp. For each species ( $\mathrm{n}$ $=45), 45$ replicates were created, with 10 individuals pooled in each replication.

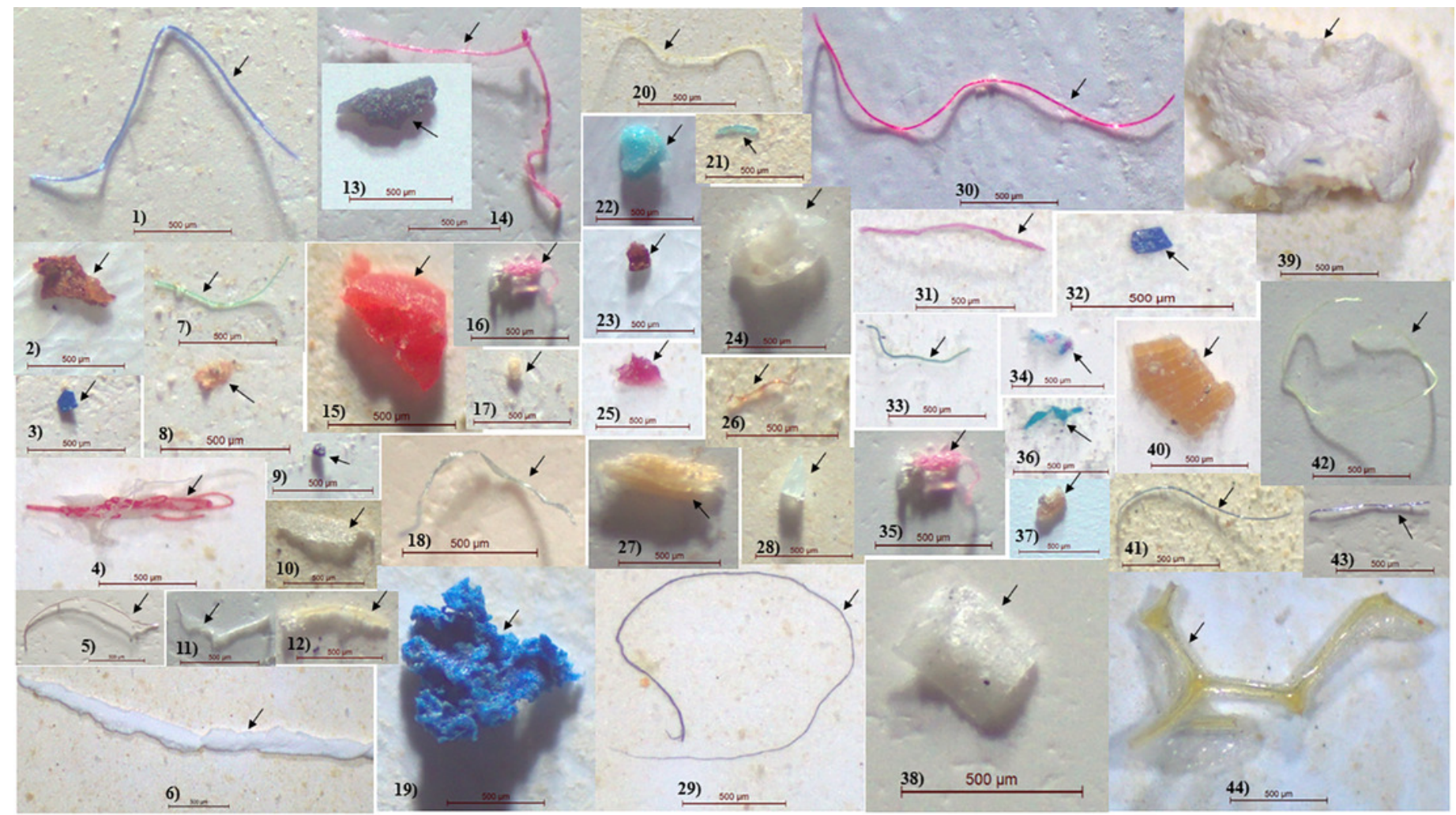




\section{Figure 3}

FT-IR analysis and photos of the most common forms of microplastics detected in

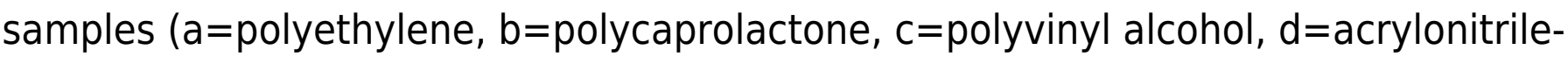
butadiene-styrene).
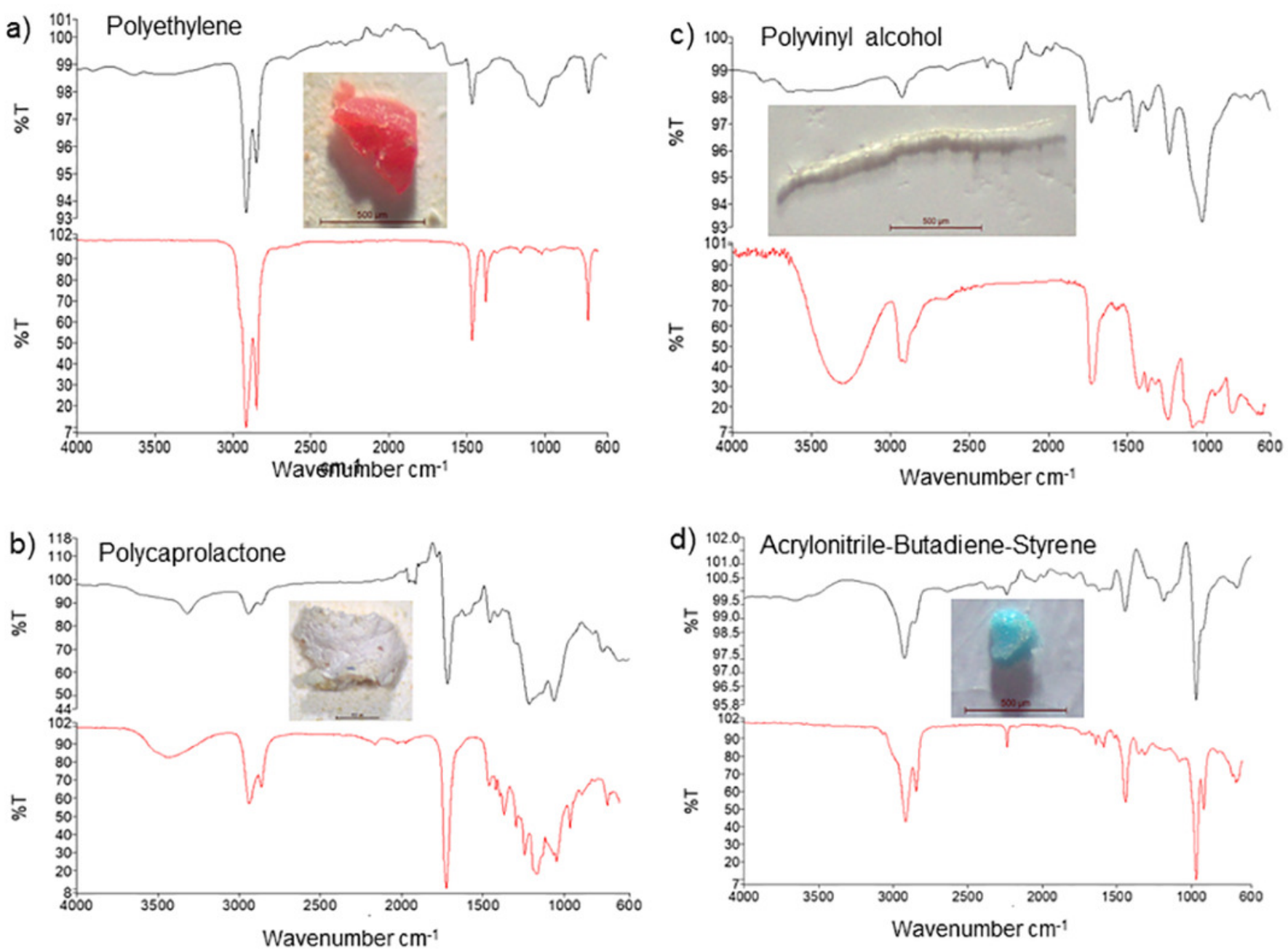


\section{Table 1 (on next page)}

Microplastic abundance in various prawn and shrimp species. 
1 Table 1 Microplastic abundance in various prawn and shrimp species.

\begin{tabular}{|c|c|c|c|c|c|c|}
\hline & & & & \multicolumn{3}{|c|}{ Microplastics (MPs) item } \\
\hline Species & $\begin{array}{l}\text { individuals } \\
\text { studied }\end{array}$ & $\begin{array}{l}\text { weight } \\
\text { (g) }\end{array}$ & $\begin{array}{l}\text { (GT) tract } \\
\text { weight }(\mathrm{g})\end{array}$ & $\begin{array}{l}\text { Total } \\
\text { MPs }\end{array}$ & $\begin{array}{c}\text { Average } \\
\text { MPs/individual }\end{array}$ & $\begin{array}{c}\text { Average } \\
\mathrm{MPs} / \mathrm{g} \\
\mathrm{GT}\end{array}$ \\
\hline $\begin{array}{l}\text { Litopenaeus } \\
\text { vannamei }\end{array}$ & $\begin{array}{l}150 \\
\text { (x } 15 \\
\text { replicates) }\end{array}$ & $\begin{array}{c}20.78 \pm \\
3.99\end{array}$ & $1.07 \pm 1.04$ & 165 & $11.00 \pm 4.60^{\mathrm{a}}$ & $\begin{array}{c}10.28 \pm \\
1.19\end{array}$ \\
\hline $\begin{array}{l}\text { Macrobrachium } \\
\text { rosenbergii } \\
\text { (female) }\end{array}$ & $\begin{array}{l}160 \\
\text { (x } 16 \\
\text { replicates) }\end{array}$ & $\begin{array}{c}23.71 \pm \\
4.72\end{array}$ & $1.02 \pm 1.01$ & 533 & $33.31 \pm 19.42^{b}$ & $\begin{array}{c}32.66 \pm \\
5.10\end{array}$ \\
\hline $\begin{array}{l}\text { Macrobrachium } \\
\text { rosenbergii } \\
\text { (male) }\end{array}$ & $\begin{array}{l}140(\mathrm{x} 14 \\
\text { replicates) }\end{array}$ & $\begin{array}{c}59.32 \pm \\
7.64\end{array}$ & $1.04 \pm 1.02$ & 468 & $33.43 \pm 19.07^{b}$ & $\begin{array}{c}32.14 \pm \\
4.85\end{array}$ \\
\hline
\end{tabular}

$2{ }^{\mathrm{a}}$ significant difference $(\mathrm{p}<0.05){ }^{\mathrm{b}}$ no significant difference $(\mathrm{p}<0.50)$. 
Table 2 (on next page)

Microplastic type and colour in two shrimp species. 
1 Table 2 Microplastic type and color in two shrimp species.

\begin{tabular}{llccc}
\hline \multirow{2}{*}{ Category of microplastics } & \multicolumn{3}{c}{ Shrimp species } \\
\cline { 3 - 5 } & Fiber & $\begin{array}{c}\text { Litopenaeus } \\
\text { vannamei }\end{array}$ & $\begin{array}{c}\text { Macrobrachium } \\
\text { rosenbergii (male) }\end{array}$ & $\begin{array}{c}\text { Macrobrachium } \\
\text { rosenbergii (female) }\end{array}$ \\
\hline Type (\%) & 46.06 & 79.91 & 83.3 \\
& Fragment & 45.45 & 16.67 & 16.33 \\
& Film & 8.48 & 2.99 & 0 \\
Color (\%) & Sphere & 0 & 0.43 & 0.38 \\
& Black & 17.58 & 10.26 & 9.38 \\
& Red & 8.48 & 2.99 & 5.25 \\
& White/transparent & 49.09 & 64.53 & 78.05 \\
& Blue & 6.67 & 9.19 & 2.06 \\
& Yellow & 17.58 & 12.61 & 5.25 \\
& Green & 0.61 & 0.43 & 0 \\
\hline
\end{tabular}

2 
Table 3 (on next page)

Polymers of microplastics identified by FT-IR. 
1 Table 3 Microplastic polymers identified via FT-IR.

\begin{tabular}{lll}
\hline Description & Number & Percentage (\%) \\
\hline Total particle measured (random selection) & 20 & $100^{\mathrm{a}}$ \\
Total polymer identified & 16 & $80^{\mathrm{b}}$ \\
PE (Polyethylene) & 13 & $65^{\mathrm{c}}$ \\
PCL (Polycaprolactone) & 1 & $5^{\mathrm{c}}$ \\
PVA (Polyvinyl alcohol) & 1 & $5^{\mathrm{c}}$ \\
ABS (Acrylonitrile-Butadiene-Styrene) & 1 & $5^{\mathrm{c}}$ \\
Total non-plastic particle & 4 & 20 \\
\hline
\end{tabular}

2 a Percentage of analyzed MP particles.

3 b Percentage of polymers in analyzed MP particles.

4 c Percentage of MP polymer type. 
Table 4 (on next page)

Studies on the presence of microplastics in shrimp species. 
1 Table 4 Studies on the presence of microplastics (MPs) in shrimp species.

2

\begin{tabular}{|c|c|c|c|}
\hline Species & Location & Microplastic abundance & References \\
\hline Crangon crangon & North Sea & $1.23 \pm 0.99$ items/individual & $\begin{array}{l}\text { Devriese et } \\
\text { al., } 2015\end{array}$ \\
\hline \multirow[t]{2}{*}{ Aristeus antennatus } & $\begin{array}{l}\text { Balearic basin, } \\
\text { northwestern } \\
\text { Mediterranean sea }\end{array}$ & $\begin{array}{l}39.2 \% \text { individuals reported to have } \\
\text { ingested MPs; Fibers dominant }\end{array}$ & $\begin{array}{l}\text { Carreras- } \\
\text { Colom et al., } \\
2018\end{array}$ \\
\hline & $\begin{array}{l}\text { Sardinia Island, } \\
\text { Mediterranean Sea }\end{array}$ & $\begin{array}{l}1.66 \pm 0.11 \text { pieces/individual; } \\
\text { Fragments dominant at } 53 \% \text {, }\end{array}$ & $\begin{array}{l}\text { Cau et al., } \\
2019\end{array}$ \\
\hline Penaeus semisulcatus & Northeast of Persian Gulf & $0.360 \mathrm{pieces} / \mathrm{g}$ of muscle & $\begin{array}{l}\text { Akhbarizadeh } \\
\text { et al., } 2019\end{array}$ \\
\hline Fenneropenaeus indicus & Cochin, Kerala, India & $\begin{array}{l}0.04 \pm 0.07 \text { pieces/individual; Fibers } \\
\text { dominant }(83 \%)\end{array}$ & $\begin{array}{l}\text { Daniel et al., } \\
2020\end{array}$ \\
\hline Penaeus monodon & $\begin{array}{l}\text { Northern Bay of Bengal, } \\
\text { Bangladesh }\end{array}$ & $\begin{array}{l}6.60 \pm 0.2 \text { pieces } / \mathrm{g} \text { of gastrointestinal } \\
\text { tract; Filaments dominant }(57 \%)\end{array}$ & $\begin{array}{l}\text { Hossain et } \\
\text { al., } 2020\end{array}$ \\
\hline Metapenaeus monoceros & $\begin{array}{l}\text { Northern Bay of Bengal, } \\
\text { Bangladesh }\end{array}$ & $\begin{array}{l}3.87 \pm 1.05 \text { pieces } / g \text { of gastrointestinal } \\
\text { tract; Filaments dominant }(58 \%)\end{array}$ & $\begin{array}{l}\text { Hossain et } \\
\text { al., } 2020\end{array}$ \\
\hline \multirow[t]{2}{*}{ Litopenaeus vannamei } & Malaysia & $\begin{array}{l}20.8 \pm 3.57 / \mathrm{g} \text { w.w.; Film dominant } \\
(97.9 \%)\end{array}$ & $\begin{array}{l}\text { Curren et al., } \\
2020\end{array}$ \\
\hline & Ecuador & $\begin{array}{l}13.4 \pm 1.42 / \mathrm{g} \text { w.w.; Film dominant } \\
(93 \%)\end{array}$ & $\begin{array}{l}\text { Curren et al., } \\
2020\end{array}$ \\
\hline Paratya australiensis & Australia & $\begin{array}{l}0.52 \pm 0.55 \text { items/individual }(24 \pm 31 \\
\text { items } / \text { g); Fibers dominant }(58.3- \\
100.0 \%)\end{array}$ & $\begin{array}{l}\text { Nan et al., } \\
2020\end{array}$ \\
\hline Metapenaeus monoceros & $\begin{array}{l}\text { North eastern Arabian } \\
\text { Sea }\end{array}$ & $\begin{array}{l}7.23 \pm 2.63 \mathrm{MPs} / \text { individual; Fiber } \\
\text { dominant }\end{array}$ & $\begin{array}{l}\text { Gurjar et al., } \\
2021\end{array}$ \\
\hline Parapeneopsis stylifera & $\begin{array}{l}\text { North eastern Arabian } \\
\text { Sea }\end{array}$ & $\begin{array}{l}5.36 \pm 2.81 \mathrm{MPs} / \text { individual; Fiber } \\
\text { dominant }\end{array}$ & $\begin{array}{l}\text { Gurjar et al., } \\
2021\end{array}$ \\
\hline Penaeus indicus & $\begin{array}{l}\text { North eastern Arabian } \\
\text { Sea }\end{array}$ & $\begin{array}{l}7.40 \pm 2.60 \mathrm{MPs} \text {./individual; Fiber } \\
\text { dominant }\end{array}$ & $\begin{array}{l}\text { Gurjar et al., } \\
2021\end{array}$ \\
\hline Litopenaeus vannamei & Thailand & $\begin{array}{l}11.00 \pm 4.60 \text { items/individual; Fiber } \\
\text { dominant }(46.06 \%) .\end{array}$ & This study \\
\hline $\begin{array}{l}\text { Macrobrachium } \\
\text { rosenbergii }\end{array}$ & Thailand & $\begin{array}{l}33.43 \pm 19.07 \text { items/individual; Fiber } \\
\text { dominant }(79.91 \% \text { in male } M . \\
\text { rosenbergii). } \\
33.31 \pm 19.42 \text { items/individual; Fiber } \\
\text { dominant }(83.3 \% \text { in female } M . \\
\text { rosenbergii). }\end{array}$ & This study \\
\hline
\end{tabular}

